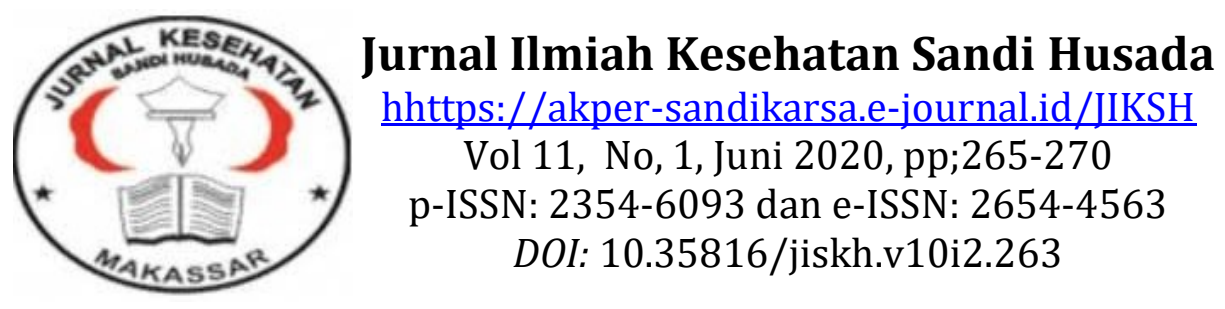

Jurnal Ilmiah Kesehatan Sandi Husada

hhttps://akper-sandikarsa.e-journal.id/JIKSH

Vol 11, No, 1, Juni 2020, pp;265-270

DOI: $10.35816 /$ jiskh.v10i2.263

\title{
Hubungan Kadar Serum Feritin dengan Kejadian Stunting pada Anak Talasemia $\beta$ Mayor
}

Relationship Between Ferritin Serum Levels and Occurrence Stunting In Children Thalassemia $\beta$ Major

\author{
Rita Agustina ${ }^{1}$, Zulhafis Mandala ${ }^{2}$, Rena Sahara ${ }^{3}$ \\ ${ }^{1}$ Dosen Fakultas Kedokteran Universitas Malahayati \\ ${ }^{2}$ Depatemen Biokimia Fakultas Kedokteran Universitas Malahayati
}

${ }^{3}$ Program Studi Kedokteran Fakultas Kedokteran Universitas Malahayati

\section{Artikel info}

Artikel history:

Received; 05 April 2020

Revised; 08 April 2020

Accepted; 09 April 2020

\begin{abstract}
Abstrak
Thalasemia adalah penyakit anemia hemolitik yang ditandai dengan adanya kelainan sintesis rantai globin. Terjadi hemakromatosis dan hipoksia jaringan akibat anemia itu merupakan faktor hormonal akibat menumpuknya zat besi pada kelenjar endokrin. Masalah dikelenjar endokrin dan kondisi anemia dapat mengganggu pertumbuhan seperti postur tubuh yang pendek. Penelitian ini untuk mengetahui hubungan kadar serum feritin dengan kejadian stunting pada anak thalasemia beta mayor di rumah sakit Abdul Moeloek Bandar Lampung Tahun 2019. Penelitian ini menggunakan metode observasional analitik dengan pendekatan cross sectional. Subjek dalam penelitian berjumlah 60 pasien. Instrumen yang digunakan adalah Data rekam medis. Hasil analisis statistik menggunakan uji Chi-Square menunjukkan ada hubungan antara kadar feritin dengan kejadian Stunting pada pasien Thalasemia $\beta$ Mayor anak di Rumah Sakit Abdul Moeloek Bandar Lampung tahun 2019 (p value 0,018. OR 4, 67). Terdapat hubungan antara kadar feritin dengan kejadian Stunting pada pasien Thalasemia $\beta$ Mayor anak di Rumah Sakit Abdul Moeloek Bandar Lampung tahun 2019
\end{abstract}

\begin{abstract}
Thalassemia is a hemolytic anemia characterized by abnormalities in globin chain synthesis. Hemachromatosis and tissue hypoxia due to anemia are hormonal factors due to the accumulation of iron in the endocrine glands. Problems with endocrine glands and anemia can interfere with growth such as short posture. This study was to determine the correlation of serum ferritin levels with the incidence of stunting in betathalassemia major children in Abdul Moeloek Hospital in Lampung in 2019. This research uses observational analytic method with cross sectional approach. Subjects in the study were 60 patients. The instrument used was medical record
\end{abstract}


data. Statistical analysis using the Chi-Square test showed an association between ferritin levels and the incidence of Stunting in Thalassemia patients $\beta$ Major children at Abdul Moeloek Hospital in Bandar Lampung in 2019 (p value 0.018. $O R$ 4.67). There is a relationship between ferritin levels with the incidence of Stunting in Thalassemia patients $\beta$ Major children at Abdul Moeloek Hospital, Bandar Lampung in 2019.

\author{
Keywords: \\ Ferritin Levels \\ Stunting \\ Thalassemia $\beta$
}

Coresponden author:

Email: sahararenaa@gmail.com

artikel dengan akses terbuka dibawah lisensi CC BY -4.0

\title{
Pendahuluan
}

Thalasemia adalah kelompok kelainan hematologik diturunkan akibat defek sintesis satu atau lebih rantai globin (Tanto, etall, 2014). Thalasemia sendiri terbagi menjadi thalasemia $\alpha$ dan $\beta$. Thalasemia $\beta$ terbagi menjadi minor, mayor dan intermedia. Thalasemia $\beta$ terjadi akibat berkurangnya rantai globin $\beta$ atau tidak diproduksi sekali rantai globin $\beta$. Sedangkan thalasemia $\alpha$ disebabkan karena berkurangnya atau tidak diproduksi sama sekali rantai globin $\alpha$ (Sudoyo, 2006). Dimana thalasemia mayor dapat menyebabkan anemia berat dengan hemolysis dan eritropoiesis yang tidak efektif karena thalasemia yang terparah (Pohan,etall, 2013). Sekitar 250 juta penduduk dunia $(4,5 \%)$ adalah carrier genetik Thalasemia, dengan 80-90 juta orang diantaranya adalah pembawa genetik thalasemia (WHO, 2006). Sedangkan menurut TIF (Thalasemia Internasional Federation) ada sebanyak 1,5\% populasi global membawa gen thalasemia dengan insidens 60.000 kelairan setiap tahunnya. Kejadian ini sering terjadi terutama di negara-negara berkembang dan hampir 90\% penyakit ini berasal dari kalangan masyarakat miskin.

Menurut Alyumnah dan Ghozali pada tahun 2015 di Indonesia, penderita penyakit thalasemia tergolong tinggi dengan semakin bertambahnya pasien thalasemia setiap tahunnya. Frekuensi gen thalasemia di Indonesia sekitar 3-10\%. Berdasarkan angka itu diperkirakan lebih dari 2000 penderita baru setiap tahunnya dilahirkan di Indonesia. Ada beberapa daerah di Indonesia yang mempunyai resiko tinggi untuk carrier gen thalasemia, seperti Batak 1,5\%, Jawa 4,3 \%, Melayu 5,2\%. Di Lampung sendiri khususnya di Rumah Sakit Abdoel Moeloek pasien thalasemia di ruang Pelayanan Anak Alamanda tercatat ada 115 pasien yang di rawat dan rutin melakukan transfusi darah di tahun 2016 (Hidayah, 2016). Penderita penyakit thalasemia tergolong tinggi dengan semakin bertambahnya pasien thalasemia setiap tahunnya yaitu di Indonesia, dimana setiap tahun akan lahir 3000 bayi yang berpotensi terkena thalasemia (Alyumnah dan Ghozali, 2015).

Thalasemia $\beta$ yang diturunkan dari kedua orang tua pembawa kode genetik thalasemia menunjukan gejala klinis yang paling berat, keadaan ini di sebut juga thalasemia $\beta$ mayor. Penderita thalasemia $\beta$ akan mengalami anemia karena penghancuran hemoglobin, membuat penderita harus tranfusi seumur hidup. Tranfusi darah yang diperlukan untuk menunjang kehidupan penderita thalasemia $\beta$ mayor yang dilakukan secara terus menerus mengakibatkan penumpukan zat besi pada organ hati dan ginjal, sehingga mengganggu fungsi kedua organ tersebut. Penderita thalasemia yang terus menerus menjalani transfusi darah, akan semakin beresiko terhadap kelain an fungsi organ tersebut (Nuari, eatall, 2016). Transfusi secara terus menerus pada pasien thalasemia bisa menyebabkan terjadi penumpukan atau penimbunan zat besi dalam tubuh terutama pada hati, jantung, dan organ endokrin. Terjadi hemakromatosis dan hipoksia jaringan akibat 
anemia itu merupakan faktor hormonal akibat menumpuknya zat besi pada kelenjar endokrin (Rafika et all, 2019).

Masalah dikelenjar endokrin dan kondisi anemia dapat mengganggu pertumbuhan seperti postur tubuh yang pendek (Mariani, 2011). Feritin merupakan protein yang berperan menyimpan zat besi dalam tubuh. Kadar Feritin sangat berguna untuk mendiagnosis keadaan defisiensi zat besi atau keadaan kelebihan zat besi. Kadar feritin berfungsi sebagai tempat penyimpanan zat besi terbesar didalam tubuh terutama hati, limfa, dan sum-sum tulang. Zat besi yang berlebihan akan disimpan dan jika diperlukan bisa dimobilisasi kembali. Kadar feritin normal berkisar antara 20g/L sampai 200g/L (Ikram dkk, 2014). Hasil penelitian sebelumnya oleh Rafika pada bulan mei tahun 2019 menyatakan bahwa Dari 43 pasien, hasil uji korelasi antara kadar feritin serum dan status gizi (indeks TB/U) didapatkan nilai $\mathrm{p}=0.005(<\alpha 5 \%)$, dengan nilai $\mathrm{r}=-0.419$ yang berarti terdapat korelasi yang cukup kuat antara kadar feritin serum dan indeks TB/U dengan arah yang negatif yaitu, bila kadar ferritin serum meningkat, maka sebaliknya indeks TB/U akan menurun (Rafika et all, 2019)

\section{Metode}

Jenis penelitian yang digunakan dalam penelitian ini adalah penelitian kuantitatif, yaitu jenis penelitian untuk memperoleh data yang berbentuk angka. Rancangan dalam penelitian ini adalah menggunakan rancangan survei analitik dengan pendekatan cross sectional yaitu mengumpulkan faktor resiko serta efeknya secara bersamaan. Penelitian ini dilakukan di Rumah Sakit Abdul Moeloek Bandar Lampung. Penelitian ini dilakukan pada bulan Januari 2020 dengan meninjau data rekam medis pasien. Pada penelitian ini teknik pengambilan sampel adalah purposive sampling. Purposive sampling ialah teknik pengambilan sampel di yang respondennya dipilih secara subjektif yang bisa memberikan informasi memadai mengenai kriteria penelitian. Besar sampel yang diambil pada penelitian ini adalah sebanyak 60 orang. Alat pengumpulan data yang di gunakan dalam melakukan penelitian adalah observasi hasil rekam medis pasien thalassemia $\beta$ mayor anak di rumah sakit abdul moeloek bandar lampung dengan pengamatan dan pencatatan data secara sistematis. Instrumen dalam penelitian ini adalah lembar observasi yang terdiri dari variabel independen dan dependen.

\section{Hasil Dan Pembahasan}

Tabel 1. Analisis antara Kadar Feritin dengan Kejadian Stunting pada pasien Thalasemia $\beta$ Mayor anak di Rumah Sakit Abdul Moeloek Provinsi Lampung tahun 2019

\begin{tabular}{cccccccc}
\hline \multirow{2}{*}{ Feritin } & \multicolumn{9}{c}{ Stunting } & \multirow{2}{*}{ Pvalue } \\
\cline { 2 - 7 } & \multicolumn{2}{c}{ Tidak } & \multicolumn{2}{c}{ Stunting } & \multicolumn{2}{c}{ Total } & \\
\cline { 2 - 6 } & $\mathrm{N}$ & $\%$ & $\mathrm{~N}$ & $\%$ & $\mathrm{~N}$ & $\%$ & \\
\hline $\begin{array}{c}\text { Tidak Beresiko } \\
=<1000\end{array}$ & 22 & 81.5 & 5 & 18.5 & 27 & 100.0 & 0,018 \\
\hline Beresiko $=\geq 1000$ & 16 & 48.5 & 17 & 51.5 & 33 & 100.0 & \\
\hline Total & 38 & 63.3 & 22 & 36.7 & 60 & 100.0 & \\
\hline
\end{tabular}

Sumber: data primer diolah

Berdasarkan hasil analisa, diketahui bahwa dari 27 responden yang memiliki kadar ferritin Tidak Beresiko $(=<1000)$, didapatkan 22 responden $(81,5 \%)$ tidak Stunting dan 5 responden $(18,5 \%)$ stunting. Sedangkan dari 33 responden yang memiliki kadar ferritin 
Beresiko ( $\geq=1000)$, didapatkan 16 responden $(48,5 \%)$ tidak stunting dan 17 responden $(51,5 \%)$ Stunting. Hasil uji statistik diperoleh nilai $p$ value 0,018 maka dapat disimpulkan bahwa ada hubungan antara kadar feritin dengan kejadian Stunting pada pasien Thalasemia $\beta$ Mayor anak di Rumah Sakit Abdul Moeloek Bandar Lampung tahun 2019. Hasil analisis diperoleh pula nilai OR 4,67 (95\% CI 1,42-15,32) yang berarti bahwa responden yang memiliki kadar feritin beresiko $(\geq=1000) 4,675$ kali lebih besar menjadi Stunting dibandingkan dengan yang memiliki kadar ferritin Tidak Beresiko $(=<1000)$.

Hasil penelitian menunjukkan ada hubungan antara kadar feritin dengan kejadian Stunting pada pasien Thalasemia $\beta$ Mayor anak di Rumah Sakit Abdul Moeloek Bandar Lampung tahun 2019 (p value 0,018). Hasil analisis diperoleh pula nilai OR 4,67 (95\% CI $1,42-15,32$ ) yang berarti bahwa responden yang memiliki kadar feritin beresiko ( $\geq=1000$ ) 4,675 kali lebih besar menjadi Stunting dibandingkan dengan yang memiliki kadar ferritin Tidak Beresiko $(=<1000)$. Transfusi secara terus menerus pada pasien thalasemia bisa menyebabkan terjadi penumpukan atau penimbunan zat besi dalam tubuh terutama pada hati, jantung, dan organ endokrin. Terjadi hemakromatosis dan hipoksia jaringan akibat anemia itu merupakan faktor hormonal akibat menumpuknya zat besi pada kelenjar endokrin (Rafika et all, 2019). Masalah dikelenjar endokrin dan kondisi anemia dapat mengganggu pertumbuhan seperti postur tubuh yang pendek (Mariani, 2011).

Feritin merupakan protein yang berperan menyimpan zat besi dalam tubuh. Kadar Feritin sangat berguna untuk mendiagnosis keadaan defisiensi zat besi atau keadaan kelebihan zat besi. Kadar feritin berfungsi sebagai tempat penyimpanan zat besi terbesar didalam tubuh terutama hati, limfa, dan sum-sum tulang. Zat besi yang berlebihan akan disimpan dan jika diperlukan bisa dimobilisasi kembali. Kadar feritin normal berkisar antara 20g/L sampai 200g/L (Ikram dkk, 2014). Kadar feritin serum diketahui berkorelasi positif dengan simpanan besi yang ada di tubuh, yang berarti semakin tinggi kadar feritin serum maka semakin tinggi simpanan besi tubuh. Kelebihan besi pada penyandang talasemia $\beta$ mayor merupakan dampak dari hipertransfusi yang dilakukan dan akan meningkatkan morbiditas serta mortalitas di kemudian harinya. Demi menjaga kelangsungan hidup mereka, maka diperlukan terapi kelasi besi yang optimal untuk mencegah hal itu. Penilaian status gizi pada penelitian ini menggunakan indeks berat badan menurut tinggi badan menurut umur (TB/U), dan berat badan menurut tinggi badan sesuai dengan kurva Center for Disease Control and Prevention (CDC) tahun 2000. Hasil penelitian sebelumnya oleh Rafika pada bulan mei tahun 2019 menyatakan bahwa Dari 43 pasien, hasil uji korelasi antara kadar feritin serum dan status gizi (indeks TB/U) didapatkan nilai $\mathrm{p}=$ $0.005(<\alpha 5 \%)$, dengan nilai $r=-0.419$ yang berarti terdapat korelasi yang cukup kuat antara kadar feritin serum dan indeks TB/U dengan arah yang negatif yaitu, bila kadar ferritin serum meningkat, maka sebaliknya indeks TB/U akan menurun (Rafika et all, 2019).

Tingginya kadar feritin serum merupakan komplikasi yang tidak bisa dihindari bagi pasien talasemia- $\beta$ mayor yang mendapatkan transfusi berulang. Kelebihan besi yang terus berlangsung menyebabkan penimbunan yang progresif di jaringan berbagai organ, yang akan diikuti dengan kerusakan yang serius pada organ tubuh khususnya jantung, hati, dan organ endokrin. Dari penelitian ini didapatkan bahwa terdapat 5 responden $(18,5 \%)$ yang memiliki kadar ferritin tidak beresiko $(=<1000)$ mengalami stunting. Kemungkinan disebabkan banyak faktor lain selain dari kadar ferritin yang tinggi yang menyebabkan kerusakan berbagai organ. Bisa banyak faktor yang menyebabkan stunting pada anak thalassemia $\beta$ mayor yaitu faktor penyebab langsung dan tidak langsung. Seperti penyebab tidak langsung yaitu tinggi badan orang tua, riwayat pemberian ASI, riwayat penyakit infeksi, ketersediaan pangan dalam rumah tangga, kemiskinan, pola asuh yang kurang memadai dan pendidikan yang rendah atau penyebab langsung stunting meliputi 
kurangnya jumlah dan kualitas makanan yang dikonsumsi dan menderita penyakit infeksi (Oktavia, 2017).

Dari penelitian ini juga didapatkan bahwa terdapat 16 responden $(48,5 \%)$ yang memiliki kadar ferritin Beresiko ( $\geq=1000$ ) tidak stunting. Walaupun kadar ferritinnya beresiko menyebabkan gizi kurang dan buruk tetapi Kemungkinan faktor dari konsumsi gizi baik pada anak thalassemia $\beta$ mayor dikarenakan kualitas makanan yang dikonsumsi sehat dan sesuai dengan gizi yang dibutuhkan. Bisa disebabkan juga karena pola asuh orang tua yang baik, ekonomi yang cukup dan memadai serta pengetahuan orang tua yang baik tentang kebutuhan gizi pada anak terutama penderita talasemia. Keterbatasan pada penelitian ini adalah tidak memperhatikan setiap faktor-faktor dan karakteristik dari setiap pasien thalassemia $\beta$ mayor anak yang menyebabkan stunting kecuali hanya melihat dari kadar ferritin. Beresiko ( $\geq=1000)$ dikarenakan instrument penelitian ini hanya melihat hasil data rekam medik saja.

\section{Simpulan Dan Saran}

Hasil penelitian diperoleh sebanyak 38 orang (63,3\%), distribusi frekuensi kadar feritin sebagian besar adalah Beresiko ( $\geq=1000)$ yaitu sebanyak 33 orang $(55,0 \%)$.menunjukkan bahwa hubungan antara kadar feritin dengan kejadian Stunting pada pasien Thalasemia $\beta$ Mayor anak di Rumah Sakit Abdul Moeloek Bandar Lampung tahun 2019 (p value 0,018. OR 4, 67) Dari hasil penelitian ini diharapkan agar meningkatkan pengetahuan ibu dengan cara penyuluhan tentang pentingnya asupan makanan yang mengandung zat gizi besi kepada keluarga perlu ditingkatkan dengan ditambah materi cara pembuatan menunya, agar ibu mudah untuk mengaplikasikan kepada anaknya. Pemberian suplementasi besi perlu dilakukan pada anak yang mempunyai kadar feritin di bawah normal untuk meningkatkan status besi anak tersebut. Meneliti faktor lain yang dapat berhubungan dengan kejadian Stunting pada penderita thalasemia seperti tingkat ekonomi keluarga dan pengetahuan ibu.

\section{Daftar Rujukan}

Alyumnah, P., Ghozali, M., \& Dalimonethe, N.(2015). Skrining Thalasemia Beta Minor pada Siswa SMA di Jatinangor Suspected Beta Thalasemia Minor Screening in Jatinangor HighSchool Student, 1, 133-138

Hidayah, F. 2016. Gambaran penderita thalassemia yang di rawat di RSUD Dr. H. Abdoel Moeoek Kota Bandar Lampung Tahun 2010-2015. Skripsi. Bandar Lampung Universitas Malahayati.

Ikram, N, dkk.(2014). Feritin Levels in Patient of Beta Thalasemia Major. Int J Pathol. Singapore.

Mariani, D. (2011). Analisis faktor yang mempengaruhi kualitas hidup anak thalasemia beta mayor di RSU KotaTasikmalaya dan Ciamis. Diperoleh tanggal 7 Januari 2015 dari http://www.lib.ui.ac.id.

Nuari,A., Tjiptaningrum, T., Ristyaningrum, P., Basuki, W. (2016). Hubungan Kadar Feritin Serum dengan Aktivitas Enzim AST, ALT, dan Status Gizi pada Anak Talasemia $\beta$ Mayor. Fakultas Kedokteran Universitas Lampung. Vol. 3, No. 1.

Oktavia, S., Widajanti, L., \& Aruben, R. (2017). Faktor-faktor yang Berhubungan dengan Status Gizi Buruk pada Balita di Kota Semarang Tahun 2017 (Studi di Rumah Pemulihan Gizi Banyumanik Kota Semarang). Jurnal Kesehatan Masyarakat (eJournal), 5(3), 186-192. 
Pohan, A., Purwaningsih,E., \& Dwijayanti,A.(2013). Efek Kelasi Etanol Daun Mangifera foetida pada Feritin Serum Penderita Thalasemia di RS Cipto Mangunkusumo, 1(1),46.

Rafika, Marwoto D, Hayati L.2019. Korelasi Antara Kadar Feritin Serum dan Status Gizi Pasien Thalassemia- $\beta$ Mayor. Journal Biomedik. Vol. 5, No. 2.

Sudoyo, W,A., Setiyadi, B., Alwi,I., Simadibrata,M,K., Setiyadi, S.(2006). Buku Ajar Ilmu Penyakit Dalam. Edisi VI. Jilid I. Jakarta Pusat Penerbitan Departemen Ilmu Penyakit dalam FK. Universitas Indonesia

Tanto, C.,Liwang, F., Hanifati, S., Pradipta, E. 2014. Kapita Selekta Kedokteran. Edisi IV Thalassemia International Federation (TIF), 2008. Guidelines for the Clinical Managementof Thalasemia : http://www.thalassemia.org.cy. Pada tanggal 14 Maret 2019

Word Health Organization (WHO), 2006. Control Of Genetic Disease di ambil dari :http://apps.who.int/gb/ebwh/pdf files/EB116/B116 3-en.pdf.pada tanggal 14 maret 2019 